\title{
SiM
}

\section{Using Homestead Records and Aerial Photos to Investigate Historical Cultivation in the United States}

\author{
By Lesley R. Morris
}

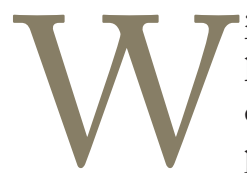

ithout consideration of prior cultivation history, we may misinterpret the results of a study or the success of management practices in rangelands. Cultivation involves plowing the soil, seeding, and harvesting a crop annually. The long-lasting impacts, known as "land-use legacies," from these disturbances on soils and native plant communities have been observed in ecosystems worldwide for decades, centuries, and even millennia after cultivation ceases. ${ }^{1}$ In sagebrush ecosystems, cultivation can be one of the most drastic disturbances, with recovery taking well over 90 years in some places. ${ }^{2,3}$ These legacies include altered vegetation, soils, and hydrology. ${ }^{4}$ The reestablishment of native species in formerly cultivated areas is typically slowed, if not halted, due to loss of native seedbanks, limited dispersal, and loss of establishment niches. ${ }^{5}$ In contrast, exotic and invasive species are often quick to establish and dominate formerly cultivated land. ${ }^{6}$ Cultivation can also modify soil structure, texture, and nutrient content. Plowing breaks up soil structure, making it more susceptible to erosion and loss of soil organic matter and nutrients. ${ }^{7}$ Plowing also can lead to soil compaction, which affects primary hydrological processes like soil water-holding capacity, run off, and infiltration., These legacies are important because they represent fundamental changes in the structure and function of ecosystems. Unfortunately, the influence of this historical land use is often overlooked in ecological studies, research design, and management implementation.

The extent and impact of cultivation legacies is widespread on rangelands in the western United States. It was estimated that nearly 23 million acres of rangeland in the western United States were cultivated and abandoned by the late 1930s. ${ }^{10}$ By the 1940s, one-fourth of the 12 million acres of degraded rangelands in the Intermountain West were reportedly abandoned plowed lands. ${ }^{11}$ In southern Idaho alone, two million acres of cultivated land had been abandoned by $1949 . .^{12}$ In the Columbia River Basin, it is estimated that $17 \%$ of the land has been affected by agriculture. ${ }^{13}$ Land-use legacies from cultivation now exist in all landownership types in the western United States including private property and public lands managed by the Bureau of Land Management (BLM), National Park Service (NPS), and US Forest Service (USFS).

Even though cultivation was prevalent during early settlement, this land use is mostly ignored when selecting research sites in the field and is not integrated into our understanding of the dynamics of ecological sites or into state and transition models for rangelands in the western United States. This is problematic because we could be setting up research plots, monitoring locations, and management practices on land where ecological processes are already fundamentally changed without our knowing it. How does a researcher or resource manager find out about historical cultivation at a site? In this article I offer a brief description for finding and using valuable documentation for the western United States that is linked to cultivation history-homestead records. I provide the basic steps for locating homestead records and aerial photographs and for interpreting a site's cultivation history from those sources. With better knowledge of how to obtain this information, perhaps its use will become more prevalent in research and management on western rangelands in the United States.

\section{What Are Homestead Records?}

Homesteading in the United States began in 1862 when Congress sought to settle the American West through the Homestead Act. ${ }^{14}$ The act allowed for a homestead (also called a "land entry") of up to 160 acres of federal land. This legislation required that the applicant (also called an "entryman," "claimant," or "patentee") be a head of household or 21 years of age, and either be a citizen of the United States or provide proof of declaration to become one. To gain the land patent (essentially the deed), applicants were required to prove five years' residence and cultivation of the land. ${ }^{14}$ Homestead records are the case files of paperwork required for applicants to obtain the patent on a piece of land in the United States. ${ }^{15}$ These files contain information about the first transfer of land into private ownership only. Records of subsequent sales are maintained by county recorders and individual state archives. ${ }^{16}$ Homestead 


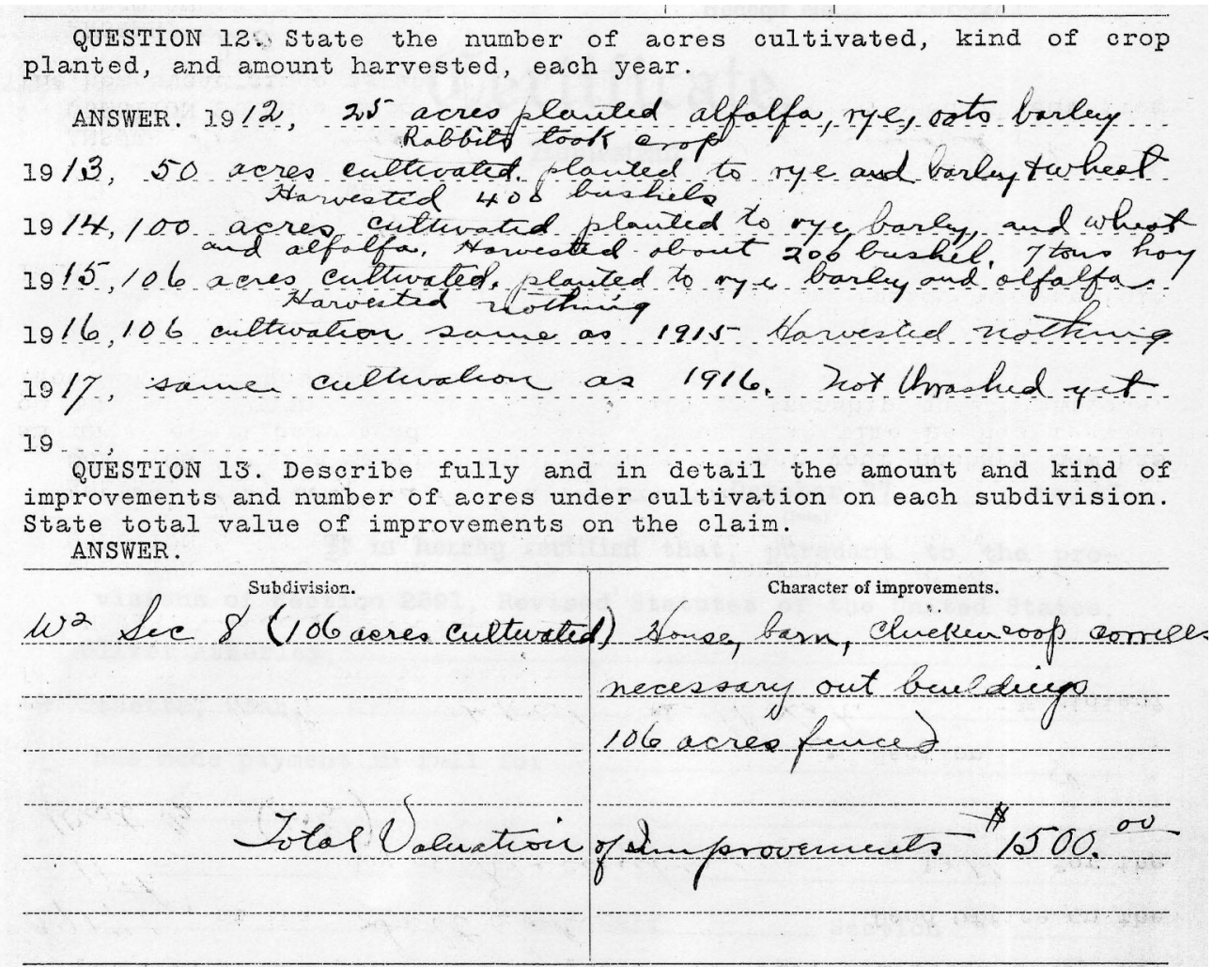

Figure 1. This portion of a claimant's testimony in a homestead record reveals how many acres were planted each year, what he planted, and how much he harvested. He does not say exactly where in his 320 acre claim the fields were located, but the size (106 acres) can be compared to aerial photos as a way of identifying it (see Fig. 2).

records can be a good source of information regarding cultivation and other land uses associated with European settlement in the West.

\section{Where to Find Homestead Records}

The BLM has a fully searchable database of land patents. ${ }^{i}$ By selecting the Search Documents tab, investigations can be initiated based on a patentee name or a serial number. Typically, however, this information may not be known; therefore, the Search by Location tab is often more useful because it searches based on the public land survey system (township, range, and section). Location searches require the state, township, range, section number, and meridian of the property of interest. The inquiry will return a list of all the successful patents filed in that particular section. The results list provides entryman's name, date of final patent, and the aliquots (division within the section). These aliquots can be used to map where each homestead was for the entire section. The accession number for each entryman's name will lead to additional information about his or her claim such as the total acreage and land office where the application

'BLM database of land patents is available at http://www.glorecords. blm.gov. was filed. All of this information is important for obtaining copies of the full homestead record.

There may be homesteads filed where the applicant was not successful at gaining ownership of the property or canceled his or her claim. In the meantime, they could have cleared the land, dry farmed, fenced, cut wood, grazed livestock, dug wells, dug irrigation ditches, etc. Tract books are used to obtain the full record of all the land entries filed on a section of land. Tract books are not available online. They can be found at the National Archives and Records Administration and its regional offices or at state BLM offices. Some states have similar records, historical indexes, online $\mathrm{e}^{\mathrm{ii}}$ or through state BLM websites.

Records for successful land patents are maintained by the National Archives and Record Administration I (NARA) in Washington, DC. NARA maintains land entry files for all states in the United States except those that were never a part of the public domain: the 13 original states, Vermont, Kentucky, Tennessee, Maine, West Virginia, Texas, and Hawaii. ${ }^{16}$ The homestead records can be accessed by the public at the NARA facility or ordered online. iii Ordering a

\footnotetext{
"http://www.glorecords.blm.gov.

iii Order National Archives and Record Administration records at http://www.archives.gov.
} 

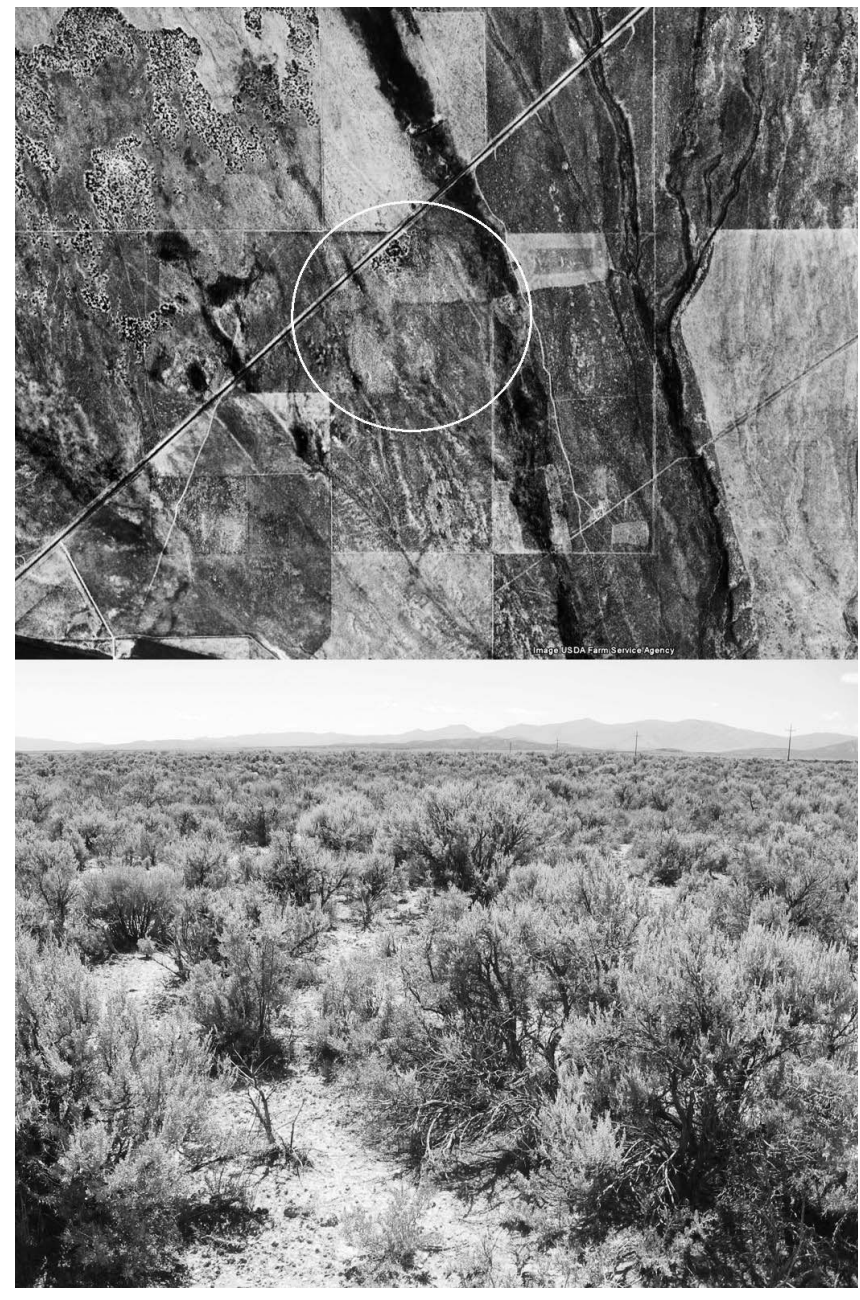

Figure 2. The top image is an aerial photo of the historically cultivated area (within circle) described in the homestead record from Figure 1 nearly a century after this land was first dry farmed (photo from USDA Farm Service Agency 2006, (C) Google 2011). The bottom image shows this same historically cultivated area from the ground (photo by author, 2009). While the historically cultivated area can be easy to see in aerial photos, it can be difficult to discern from the ground.

record requires signing in and creating an account. The information needed to retrieve the correct record includes entryman's first and last name, date of patent, serial patent number, state of the homestead, and land office used. All of these facts can be obtained through land patent searches at the BLM website discussed above. The cost for a paper copy of the entire case file at the time this article was published was $\$ 40.00$ including shipping.

\section{Interpreting Homestead Records}

Homestead records, especially those after 1908, offer very specific information about how many acres were cultivated each year, what was planted, and where the fields and other improvements (e.g., structures and wells) were located. The full homestead record from NARA will be multiple pages long and includes materials such as the certificate of

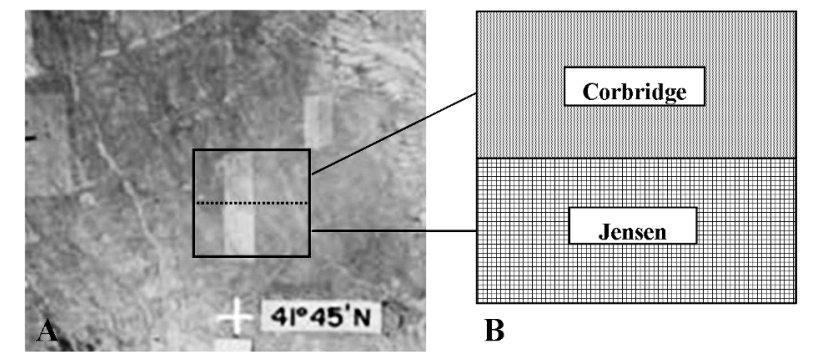

Figure 3. A, In this aerial photo from 1956, section and half section lines have been added for illustration (photo for USGS). This image demonstrates how cultivated areas appear as lighter colored areas and squared off with straight edges within the section of interest. B, The results list from a patent search on the BLM website gives the locations of the two homesteads in this section. Corbridge homesteaded the northern half (320 acres), and Jensen homesteaded the southern half (320 acres).

homestead, application, receipts and publication notices, and final proof paperwork (testimony of the claimant and witnesses). The testimony of both the claimant and two witnesses was required to ensure that all of the provisions of the law had been met. These testimonies, particularly those of claimants, provide the details of the land use on the homestead (Fig. 1).

Since the allowable acreage for homesteading grew over time, the date a patent was filed and the total acreage of the homestead also provide clues about its use. Irrigation agriculture and livestock grazing were primary land uses during this era. Between 1900 and 1909, the popularity of dry farming (cultivation without irrigation) was on the rise in the United States, and there was an increase in homestead entries as people attempted to settle and dry farm. ${ }^{15}$ It was soon discovered that 160 acres was not enough land under the Campbell method of dry farming, which required rotations of fallowed and planted land. ${ }^{15,16}$ There were many failed homestead entries during this time, which is why tract books and aerial photos should be used in conjunction with successful homestead records.

In response to the call for larger tracts to dry farm, the Enlarged Homestead Act doubled the acreage available for patent from 160 acres to 320 acres. It was the first homesteading legislation that required a specific amount of acreage be cultivated each year. Under this new law, 20 acres had to be under cultivation by the second year and 40 acres continuously under cultivation from the third year to the final year. ${ }^{15}$ Not wanting to be branded as "semiarid," five states asked to be exempted from the legislation but joined later: California (joined 1910), Idaho (joined 1910), Kansas, North Dakota (joined 1912), and South Dakota (joined 1915). ${ }^{14}$ Under the Desert Land Act of 1877, applicants could file for up to 640 acres if they could prove within three years that they had reclaimed the land for irrigation. In later years, this act was modified so that one could file under authority of both the Desert Land and Enlarged Homestead 


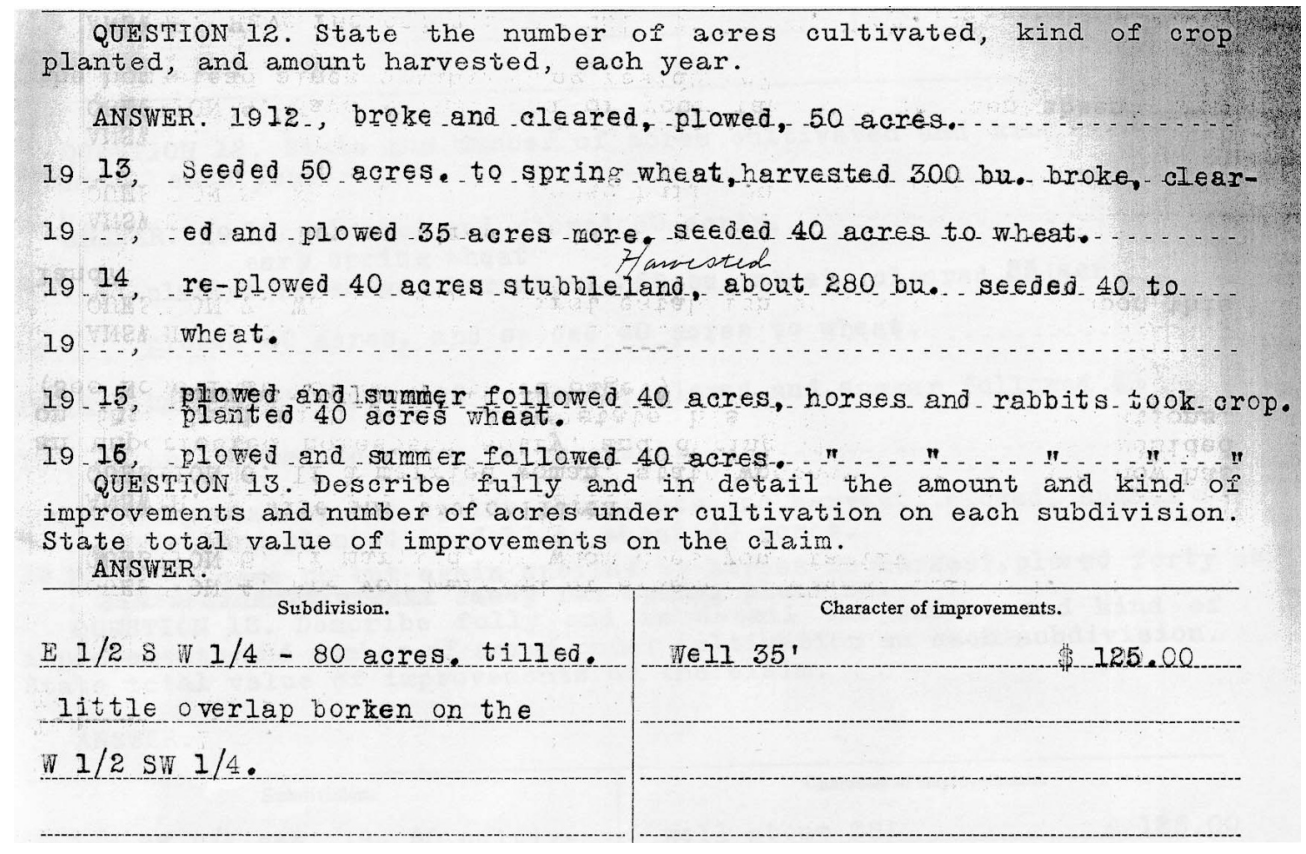

Figure 4. According to the claimant testimony in Corbridge's homestead record, he tilled 80 acres in the east half of the southwest quarter ( $E$ 1/2 of the SW $1 / 4$ ) on his property. The area he cultivated is still visible in the aerial photo in Figure $3 \mathrm{~A}$ in the location he described.

Acts for up to 480 acres with a reduced cultivation and residence requirement. ${ }^{14}$ The Enlarged Homestead Act was the most highly utilized of all the homestead laws. ${ }^{14,15}$ Fueled by the optimism about dry farming, over 18 million acres of land were entered for patent under the Enlarged Homestead Act in the first year alone. However, its popularity was as widespread as its failures. Within a decade, abandonment of dry farms across the West rose as the price of wheat fell and droughts spread across the United States.

In 1916 Congress again increased the acreage for entry to 640 acres under the Stock Raising Homestead Act. This act required proof of improvements to increase the value of the land such as fencing, wells and water installations, or raising forage crops. In other words, there was no specific requirement for cultivation, but that did not mean it did not happen. There were reports that some people took out entries but did not have the capital to buy livestock. In this case, homesteaders did the bare minimum to gain title (e.g., built crude shacks) and then took jobs in town and planted wheat to get by until they could sell the land to a livestock operation. ${ }^{14}$ The participation of the United States in World War I further encouraged cultivation during this period. Not only was growing wheat considered a patriotic activity to support the war effort, but the price was subsidized by the federal government during the war to ensure a steady supply. ${ }^{17}$

Knowing this history, the date and size of the final patent can provide a hint of the land use for a given homestead. For example, if a patent was approved after 1909 and was for 320 acres, it was likely an Enlarged Homestead and had at least 40 acres of cultivation. Or, if the patent was approved between 1916 and 1919 (end of World War I) and is 640 acres in size, it was likely a Stock Raising Homestead and could have included at least a little wheat cultivation on the land. One way to confirm if or how much land was under cultivation is through examining aerial photos.

\section{Where to Find Aerial Photos}

Aerial photographs are another way of looking for historic cultivation. Evidence of cultivation can sometimes be seen in aerial photos nearly a century after the land use has ceased, even when it is not visible on the ground (Fig. 2).,16 From the air, cultivation often stands out as lighter colored areas (in part because of the bare ground) with distinct edges. Although some fields were cultivated along the contour of hillsides or other topographic barriers, most fields are squared off and easy to recognize. However, sometimes formerly cultivated areas are difficult to identify because they are masked by wildfires or other subsequent land uses (e.g., rangeland seedings). ${ }^{4,18}$ This is why having the homestead record is so important for confirming where cultivation took place.

Aerial photos can be located through a number of sources on the internet. The USDA Farm Service Bureau Aerial Photography Field Office (APFO) website ${ }^{\text {iv }}$ maintains searchable databases of aerial photos. There are instructions

\footnotetext{
iv The Farm Service Bureau's aerial photographs can be accessed at http://www.fsa.usda.gov/FSA.
} 

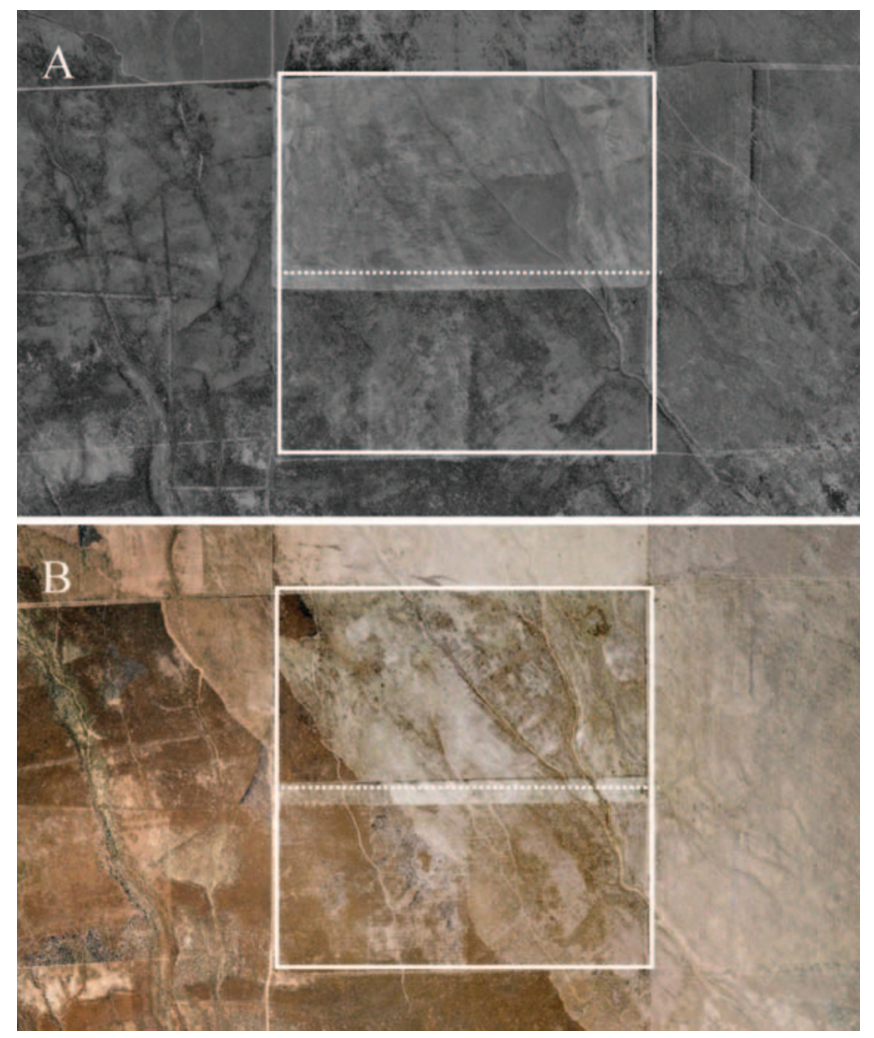

Figure 5. A, This aerial photo shows the same section in 1999 (photo from MSR maps). The northern half of the section, Corbridge's homestead, has been seeded, and so the outline of the dry farm fields is less visible. B, This aerial photo from 2006 shows the same section burned after 1999, making both fields harder to see (photo from USDA Farm Service Agency 2006, (c) Google 2011).

on how to search the comprehensive text files by state or county with different browsers. The search results list aerial images on file with the APFO by county. Aerial photos can be ordered directly from the APFO via the website. The US Geological Survey (USGS) Earth Explorer websitev can be searched by specific locations using place names or latitude and longitude coordinates. Aerial photos can be previewed, downloaded, or purchased on this site. The Microsoft ${ }^{\circledR}$ Research Maps (MSR maps) website ${ }^{\text {vi }}$ provides previews of aerial images where the user can toggle between a topographic map and the aerial image. The user can also zoom in or out on the aerial image and download and save them for free. Finally, Google Earth ${ }^{\mathrm{TM}}$ is free software that can be downloaded from the internet. ${ }^{\text {vii }}$ This software is easy to use and contains many aerial images around the globe. There are also historical aerial photos available, depending upon location, through the clock icon in the tool bar. Printed aerial photos can sometimes be viewed at district offices

\footnotetext{
${ }^{\vee}$ The USGS Earth Explorer website can be accessed at http://edcsns 17. cr.usgs.gov/EarthExplorer.

vi The MSR maps are available at http://msrmaps.com.

vii Google Earth is available at http://earth.google.com.
}

of the BLM and USFS and at headquarters for units in the NPS.

\section{Putting Homestead Records and Aerial Photos Together}

The following example shows how combining land patent records with aerial photos can work.

A 1956 aerial photo located on the USGS Earth Explorer website shows there are old fields within the section shown (Fig. 3A). According to the land patent search on the BLM website, this section had two homesteads. In 1911 Corbridge homesteaded the northern half of the section (320 acres), and Jensen homesteaded the southern half (320 acres) (Fig. 3B). Given the sizes and the dates of filing, these were likely Enlarged Homesteads, which means at least 40 acres were cultivated in each homestead. The homestead record ordered from the NARA website shows that Jensen cultivated 80 acres on the east half of the southwest quarter (E $1 / 2$ of the SW 1/4) on his homestead (Fig. 4). The 80 acres he cultivated are visible in the aerial photo in the exact location described by the homestead record (Fig. 3A). According to homestead records, Corbridge also plowed 80 acres, though his testimony does not give the specific location. It appears from the 1956 aerial photo that these two 80 acre fields lined up across the northern and southern halves of the section. An aerial photo from 1999 obtained from the MSR map website shows there was an additional rangeland seeding on the northern half, the Corbridge homestead (Fig. 5A). A 2006 aerial image from Google Earth shows how the edges of the old fields can be obscured by later disturbances, such as the fire that burned across this section (Fig. 5B). Past fires can be difficult to positively identify in aerial photos, but there are usually records of recent ones to use for confirmation.

Without knowing that portions of this section were historically cultivated, research plots could unknowingly be placed in sites where the ecological processes have already been altered and results could be misinterpreted. Similarly, management treatments such as revegetation or fuels reduction may have different outcomes across these two sites. For example, recent studies indicate that rangeland seedings may perform differently on previously cultivated land than on land never cultivated in the past (L. R. Morris, T. Monaco, and R. Sheley, unpublished data, 2011). Finally, management classification and monitoring in this property could be misled without an understanding of the history at this site.

\section{Conclusion}

Using homestead records and aerial photographs to investigate the site history of cultivation is fairly straightforward once a researcher or manager knows where to look. The visual evidence in aerial photos and on the ground can be limited at times, as can the information provided in land entry records. Therefore, the most thorough investigation should combine both of these archival records with examination on the ground for additional evidence (e.g., 
plow pan layers or rock piles). Personal interviews with former and current land owners can further expand site history knowledge. ${ }^{19}$ Knowing land-use history at a site will improve research questions, research design, land management, and restoration efforts.

\section{Acknowledgments}

I would like to thank Thomas A. Monaco, Marshall Bowen, Maggie Orr, and two anonymous reviewers for their comments and suggestions on this manuscript. I am grateful to the community members of Park Valley and Rosette, Utah, for their assistance and hospitality. Special thanks also to Neil West for backing my interest in this type of research and to Roger Sheley and Brenda Smith for encouraging me to write a paper explaining how to access these records.

\section{References}

1. Foster, D., F. Swanson, J. Aber, I. Burke, N. Brokaw, D. Tilman, and A. Knapp. 2003. The importance of land-use legacies to ecology and conservation. BioScience 53:77-88.

2. Beedlow, P. A., P. Van Voris, and L. E. Rogers. 1988. Theoretical perspective on ecosystem disturbance and recovery. In: W. H. Rickard, L. E. Rogers, B. E. Vaughn, and S. F. Liebetrau [EDS.]. Shrub-steppe: balance and change in a semi-arid terrestrial ecosystem. Amsterdam, the Netherlands: Elsevier. p. 257-269.

3. Morris, L. R., T. A Monaco, and R. L. Sheley. 2011. Land-use legacies and vegetation recovery 90 years after cultivation in Great Basin sagebrush ecosystems. Rangeland Ecology E Management 64:488-497.

4. Morris, L. R. 2011. Land-use legacies of cultivation in shrublands: ghosts in the ecosystem. In: T. A. Monaco, E. W. Schupp, S. G. Kitchen, R. L. Pendleton, and P. K. Palacios [comps.]. Proc. 16th Wildland Shrub Symposium; 25-27 May 2010; Logan, UT, USA. Natural Resources and Environmental Issues 17:11-16.

5. Cramer, V. A., R. J. Ноbbs, and R. J. Standish. 2008. What's new about old fields? Land abandonment and ecosystem assembly. Trends in Ecology and Evolution 23:104-112.

6. Cramer, V. A., And R. J. Новbs. 2007. Old fields: dynamics and restoration of abandoned farmland. Washington, DC, USA: Island Press. 352 p.

7. McLauchlan, K. 2006. The nature and longevity of agricultural impacts on soil carbon and nutrients: a review. Ecosystems 9:1364-1382.

8. Schwartz, R. C., S. T. Evett, and P. S. Unger. 2003. Soil hydraulic properties of cropland compared with reestablished and native grasslands. Geoderma 116:47-60.
9. Standish, R. J., V. A. Cramer, S. L. Wild, and R. J. Нobbs. 2007. Seed dispersal and recruitment limitation are barriers to native recolonization of old-fields in western Australia. Journal of Applied Ecology 44:435-445.

10. Stewart, G. 1938. Revegetating man-made deserts. Journal of Forestry 36:853-855.

11. Pearse, C. K., And A. C. Hull. 1943. Some economic aspects of reseeding rangelands. Journal of Forestry 41:346-358.

12. Stewart, G., and A. C. Hull. 1949. Cheatgrass (Bromus tectorum L.) - an ecologic intruder in southern Idaho. Ecology 30:58-74.

13. Bunting, S. C., J. L. Kingery, and M. A. Schroeder. 2003. Assessing the restoration potential of altered rangeland ecosystems in the Interior Columbia Basin. Ecological Restoration 21:77-86.

14. Gates, P. W. 1968. History of public land law development. Washington, DC, USA: Public Land Law Review Commission. $828 \mathrm{p}$.

15. Peffer, E. L. 1972. The closing of the public domain: disposal and reservation policies 1900-50. New York, NY, USA: Arno Press. 372 p.

16. Morris, L. R., T. Monaco, C. Call, R. Sheley, and M. Ralphs. 2011. Lessons from a century of demonstration projects in Park Valley, UT. Rangelands 33(2):2-9.

17. Hawnins, K. 1997. Research in the land entry files of the General Land Office, Record Group 49. General Information Leaflet Number 67, National Archives and Records Administration. Available at: http://www.archives.gov/publications/ general-info-leaflets/67-land-entry-files.html. Accessed 3 June 2011.

18. Hyde, D. C. 1937. National economic policy: the World War. Southern Economic Journal 4:180-194.

19. Morris, L., And T. Monaco. 2011. Researching cultivation history: a step-by-step guide to obtaining historical records. Available at: http://www.ebipm.org/content/1105. Accessed 1 October 2011.

Author is a Research Associate with the USDA-ARS Forage and Range Research Laboratory, Utah State University, Logan, UT 84322, USA, and an Adjunct Faculty Member, Natural Resource and Environmental Science Dept, University of Nevada-Reno Reno, NV 89557,USA, LesleyRMorris@gmail.com. Mention of a proprietary product does not constitute a guarantee or warranty of the product by USDA or the author and does not imply its approval to the exclusion of the other products that also may be suitable. This research was funded by the USDA-ARS-wide Ecologically Based Invasive Plant Management (EBIPM) project. 